\title{
FAKTOR-FAKTOR YANG MEMPENGARUHI KONVERSI LAHAN PERTANIAN DAN HUBUNGANNYA TERHADAP KESEJAHTERAAN PETANI SUBAK SAIH DI KECAMATAN KUTA UTARA, KABUPATEN BADUNG
}

\author{
The Factors That Affect The Agricultural Land Conversion And Its Relation To \\ The Farmers Welfare Of Subak Saih, District Of North Kuta Badung Regency
}

\author{
Kadek Dwi Andika, Wayan Windia, Ketut Suamba \\ Program Studi Magister Agribisnis, Fakultas Pertanian, Universitas Udayana, Bali, Indonesia
}

E-mail: andikamavrodi@gmail.com

\begin{abstract}
Conversion of agricultural land into one of the many polemics facing agriculture in Bali. The increasing population growth and declining agricultural output has implications for land conversions increasingly unstoppable. Faced with the problem of research about the faktors that affect the conversion of agricultural land and its relation to the welfare of farmers were conducted to obtain a solution to the phenomenon. The series of research methods used in this research is descriptive quantitative method to samples taken by proportional random sampling of 125 respondents. Data analysis using descriptive statistical techniques and statistical analysis was done through the program SemPLS. The findings obtained are: 1) Conversion of land in Saih Subak is positively influenced by: city growth faktors, economic, sosial, technology, accessibility, risks and uncertainties and the land as an asset. 2) conversion of agricultural land and its relation to the welfare of farmers showed a positive and significant relationship through accessibility, economic, land as an asset, urban growth, agricultural technology, risks and uncertainties, and sosial with the welfare of farmers. On these findings, the government and the Subak Saih must control the rate of land conversion happens. Extension and intensification of agriculture needs to be done to improve agricultural yields, reinforce government regulations, improve farm management and agricultural insurance to provide farmers minimize losses due to natural disasters. To improve the welfare of farmers, technology and the development of agri-business management is needed so that land use can be controlled and well-being can be achieved through the activities of the agricultural sector.
\end{abstract}

Keywords: conversion, welfare, Subak

\section{ABSTRAK}

Konversi lahan pertanian menjadi salah satu dari banyak polemik yang dihadapi pertanian di Bali. Meningkatnya pertumbuhan penduduk dan menurunnya output pertanian berimplikasi pada konversi lahan semakin tak terbendung. Menghadapi permasalahan tersebut, penelitian tentang faktor-faktor yang mempengaruhi konversi lahan pertanian dan hubungannya dengan kesejahteraan petani dilakukan untuk mendapatkan solusi terhadap fenomena tersebut. Rangkaian metode penelitian yang digunakan dalam penelitian ini adalah metode deskriptif kuantitatif dengan sampel yang diambil secara proportional random sampling sebanyak 125 responden. Analisis data menggunakan teknik statistik deskriptif dan analisis statistik dilakukan melalui program SemPLS. Temuan yang diperoleh adalah: 1) konversi lahan di Saih Subak secara positif dipengaruhi oleh: faktor pertumbuhan kota, ekonomi, sosial, teknologi, aksesibilitas, risiko dan ketidakpastian dan tanah sebagai asset; 2) konversi lahan pertanian dan hubungannya dengan kesejahteraan petani menunjukkan hubungan yang positif dan signifikan melalui aksesibilitas, ekonomi, lahan sebagai aset, pertumbuhan perkotaan, teknologi pertanian, risiko dan ketidakpastian, dan sosial dengan kesejahteraan petani. Berdasarkan hasil tersebut, pemerintah dan Subak Saih harus mengendalikan laju konversi lahan yang terjadi. Perluasan dan intensifikasi pertanian perlu dilakukan untuk memperbaiki hasil pertanian, memperkuat peraturan pemerintah, memperbaiki pengelolaan pertanian dan asuransi pertanian sehingga petani dapat meminimalkan kerugian akibat bencana alam. Untuk meningkatkan kesejahteraan petani, teknologi dan pengembangan pengelolaan agribisnis sangat dibutuhkan agar pemanfaatan lahan dapat dikendalikan dan kesejahteraan dapat dicapai melalui kegiatan sektor pertanian. 
Kata kunci: konversi, kesejahteraan, Subak

\section{PENDAHULUAN}

\section{Latar Belakang}

Fenomena konversi lahan marak terjadi khususnya di wilayah Kabupaten Badung yang ditandai dengan berubahnya lahan pertanian menjadi lahan untuk hunian dan perumahan. Salah satu daerah Kabupaten Badung terkait fenomena ini adalah Kecamatan Kuta Utara. Berdasarkan temuan lapangan, para petani lebih memilih mengkonversikan lahan mereka karena penghasilan dari bercocok tanam dirasa sudah tidak mencukupi untuk memenuhi kebutuhan keluarga mereka. Banyak juga yang merelakan lahan mereka kepada investor karena tergiur dengan iming-iming harga lahan yang tinggi.

Fenomena tersebut yang kemudian dimunculkan sebagai indikasi penyebab atas terjadinya konversi lahan yang demikian pesat di wilayah Kecamatan Kuta Utara, khususnya di lingkungan Subak Saih. Konversi yang telah terjadi di lingkungan Subak Saih Kecamatan Kuta Utara tergolong signifikan dan memuncak pada tahun 2014 dan menurun pada periode 2015-2016. Sehubungan dengan hal tersebut, penelitian dititikberatkan pada sebuah organisasi tradisional sebagai sistem pertanian di kawasan Kecamatan Kuta Utara yaitu Subak Saih, Kecamatan Kuta Utara, Kabupaten Badung. Melihat kondisi tersebut, logikanya konversi lahan pertanian artinya mengkonversi sumber penghasilan petani atau bahkan menghilangkan pekerjaan petani. Fenomena yang dapat diteliti di sini adalah faktorfaktor yang mempengaruhi petani untuk mengkonversikan lahan pertaniannya serta hubungan antara konversi lahan pertanian terhadap tingkat kesejahteraan rumahtangga petani.

\section{Rumusan Masalah}

Berdasarkan latar belakang di atas maka dalam penelitian ini masalah yang diajukan adalah sebagai berikut:

1. Faktor-faktor apa saja yang berpengaruh terhadap konversi lahan pertanian Subak Saih Kecamatan Kuta Utara Kabupaten Badung?

2. Bagaimana hubungan konversi lahan pertanian terhadap kesejahteraan petani di Subak Saih Kecamatan Kuta Utara Kabupaten Badung?

\section{Tujuan Penelitian}

Sebagaimana disampaikan melalui rumusan di atas maka tujuan yang ingin dicapai dalam penelitian ini adalah sebagai berikut:

1. Untuk mengetahui faktor-faktor yang mempengaruhi terjadinya konversi lahan pertanian pada Subak Saih Kecamatan Kuta Utara Kabupaten Badung.
2. Mengetahui hubungan konversi lahan pertanian dengan kesejahteraan petani di Subak Saih Kecamatan Kuta Utara Kabupaten Badung.

\section{KAJIAN PUSTAKA}

\section{Lahan Pertanian}

Menurut Notohadikusumo (2005), lahan adalah jabaran operasional kawasan. Lahan (land) ialah hamparan darat yang merupakan suatu keterpaduan sejumlah sumberdaya alam dan budaya. Lahan mengandung sejumlah ekosistem dan sekaligus juga menjadi bagian dari ekosistem-ekosistem yang dikandungnya.

\section{Subak}

Subak adalah organisasi kemasyarakatan yang khusus mengatur sistem pengairan sawah yang digunakan dalam cocok tanam padi di Bali. dalam perkembangannya Subak biasanya memiliki pura yang dinamakan Pura Uluncarik atau Pura Bedugul yang khusus dibangun oleh para petani dan diperuntukkan bagi dewi kemakmuran dan kesuburan Dewi Sri.

\section{Konversi Lahan}

Utomo dkk. (1992) mendefinisikan alih fungsi lahan atau lazim disebut dengan konversi lahan sebagai perubahan penggunaan atau fungsi sebagian atau seluruh kawasan lahan dari fungsinya semula (seperti yang direncanakan) menjadi fungsi lain yang membawa dampak negatif (masalah) terhadap lingkungan dan potensi lahan sendiri. Irawan (2004) mengungkapkan bahwa konversi lahan berawal dari permintaan komoditas pertanian terutama komoditas pangan yang kurang elastis terhadap pendapatan dibanding permintaan komoditas non pertanian. Saefulhakim dan Nasution (1995) memaparkan beberapa faktor yang berperan penting yang dapat menyebabkan proses konversi lahan pertanian ke non pertanian adalah faktor pertumbuhan kota, faktor ekonomi, faktor sosial, fakror teknologi, faktor aksesibilitas, faktor resiko dan ketidakpastian, dan faktor penguasaan lahan sebagai aset.

\section{Kesejahteraan Petani}

Menurut Yosep seperti yang dikutip Maharani (2006), kesejahteraan itu bersifat luas yang dapat diterapkan pada skala sosial besar dan kecil misalnya keluarga dan individu. Konsep kesejahteraan atau rasa sejahtera yang dimiliki bersifat relatif, tergantung bagaimana penilaian masing-masing individu terhadap kesejahteraan itu sendiri. Berbagai aspek mengenai indikator kesejahteraan dibahas oleh BPS (2004), antara lain: 
kependudukan, kesehatan dan gizi, pendidikan, ketenagakerjaan, taraf dan pola konsumsi, perumahan dan lingkungan dan sosial budaya

\section{KERANGKA KONSEP DAN HIPOTESIS}

\section{Kerangka Konsep}

Keputusan mengkonversi lahan pertanian produktif dalam hal ini berimplikasi pada kesejahteraan petani di lingkungan Subak Saih Kecamatan Kuta Utara, Kabupaten Badung. Konversi dilakukan karena dua kemungkinan yaitu usaha petani untuk memperoleh peningkatan penghasilan melalui alih fungsi lahan pertanian menjadi lahan non pertanian atau menjual atau pemindah tanganan hak kuasa tanah untuk mendapatkan kemungkinan penghasilan yang lebih baik. Konversi lahan pertanian menjadi lahan bukan pertanian tentu berhubungan erat dengan kesejahteraan petani. Ketika lahan pertanian telah dikonversi maka penghasilan dan pendapatan petani mengalami pengaruh yang signifikan baik peningkatan ataupun penurunannya. Berdasarkan atas pendangan tersebut fenomena ini kemudian dikaji secara lebih empiris melalui penelitian. Hasil penelitian disampaikan kembali dalam bentuk rekomendasi yang diberikan pada Subak Saih sebagai bahan pertimbangan.

\section{Hipotesis Penelitian}

Berdasarkan atas tahapan sebagaimana disampaikan melaui deskripsi di atas maka hipotesis yang diajukan dalam penelitian ini adalah sebagai berikut:

1. Ada pengaruh antara faktor perkembangan perkotaan, ekonomi, sosial, teknologi, aksesibilitas, resiko dan ketidakpastian, dan lahan sebagai aset terhadap konversi lahan pertanian pada Subak Saih Kecamatan Kuta Utara Kabupaten Badung

2. Ada hubungan faktor konversi lahan pertanian terhadap kesejahteraan petani Subak Saih Kecamatan Kuta Utara Kabupaten Badung.

\section{METODE PENELITIAN}

Penelitian ini dirancang dengan memanfaatkan model penelitian kuantitatif. Hal ini bertujuan untuk mengetahui faktor-faktor yang mempengaruhi konversi lahan dan hubungannya terhadap kesejahteraan petani, di tengah semakin meningkatnya konversi lahan pertanian menjadi lahan non pertanian. Lokasi penelitian di Subak Saih Kecamatan Kuta Utara Kabupaten Badung. Penelitian dilaksanakan pada bulan September sampai dengan November 2016. Populasi dalam penelitian ini adalah anggota organisasi tradisional Subak Saih di Kecamatan Kuta Utara, Kabupaten Badung. Penentuan jumlah responden ditentukan dari seluruh populasi yaitu seluruh anggota Subak Saih yang di formulasi dengan menggunakan formulasi Slovin dengan jumlah sampel dalam penelitian ini berjumlah 125 orang responden. Pengumpulan data penelitian menggunakan beberapa rangkaian metode antara lain wawancara mendalam, observasi dan metode dokumentasi.

Prosedur selanjutnya adalah dengan uji reliabilitas menunjukkan pada satu pengertian bahwa sesuatu instrument cukup dapat dipercaya untuk digunakan sebagai alat pengumpulan data karena instrument tersebut sudah baik. instrumen yang sudah dapat dipercaya, yang reliabel, akan menghasilkan data yang dapat dipercaya (Arikunto, 2013 : 238). Kriteria suatu instrumen penelitian dikatakan reabel dengan menggunakan teknik Alpa Cronbach, bila koefisien reliabilitas $\left(r_{11}\right)>0,6$. Penelitian ini dilaksanakan dengan menggunakan dua tahapan yaitu analisis deskriptif dan analisis statistik melalui program analisis SemPLS. Terdapat unsur utama dalam proses analisis data pada penulisan kualitatif yaitu: (1) Pengumpulan data; (2) Penilaian data; (3) Interprestasi data; dan (4) Menarik kesimpulan (Winarno, 2002). Analsisi data dilakukan dengan menggunakan teknik SemPLS guna membantu peneliti untuk mendapatkan nilai variabel laten untuk tujuan prediksi.

\section{HASIL DAN PEMBAHASAN \\ 3 \\ 4}

Faktor-faktor yang mempengaruhi konversi lahan pertanian dan hubungannya terhadap kesejahteraan petani sebagaimana diperoleh melalui rangkaian analisis lapangan di Subak Saih, Kecamatan Kuta Utara, Kabupaten Badung, dapat dilihat melalui hasil uji statistik yang ditampilkan melalui Gambar 1.

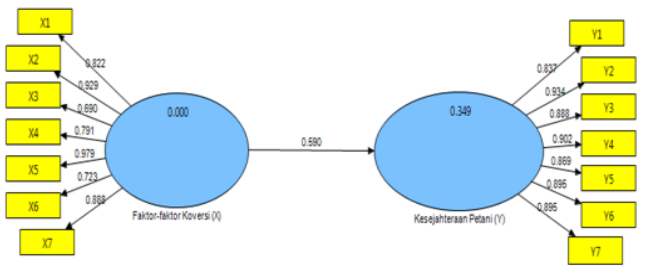

Gambar 1 : model persamaan struktural

Hasil analisis jalur sebagaimana disampaikan melalui Gambar 1. tersebut, maka faktor-faktor yang mempengaruhi konversi lahan pertanian dan hubungannya terhadap kesejahteraan petani dapat dijelaskan sebagai berikut.

Faktor-faktor yang mempengaruhi konversi lahan pertanian di Subak Saih

Berdasarkan hasil analisis yang diperoleh melalui penelitian ini dinyatakan bahwa faktor-faktor penyebab konversi yaitu dinamika pertumbuhan

Dwi Andika, et.al., Faktor-faktor... $\mid 9$ 
kota, ekonomi, sosial, teknologi, aksesibilita, risiko dan ketidak pastian, dan kedudukan lahan sebagai asset, ternyata memiliki hubungan signifikan dengan konversi lahan pertanian di Subak Saih, Kecamatan Kuta Utara, Kabupaten Badung. Hal ini dapat ditunjukkan oleh koefisien jalur yang bernilai positif sebesar 0,590 dengan t-statistik sebesar 3,201 atau t-statistik > 2,64 (dapat dilihat pada Gambar 1) sehingga hipotesis 1 : faktor dinamika pertumbuhan kota, ekonomi, sosial, teknologi, aksesibilitas, risiko dan ketidak pastian, dan kedudukan lahan sebagai asset berhubungan signifikan dengan konversi lahan pertanian dapat diterima. Hasil penelitian ini menunjukkan bahwa faktor penyebab konversi lahan pertanian di Subak Saih memiliki kontribusi yang besar sebagai pemicu terjadinya konversi lahan pertanian. Faktor-faktor tersebut harus ditangani dengan lebih intensif untuk menanggulangi tingkat konversi di wilayah pertanian Subak Saih, Kecamatan Kuta Utara, Kabupaten Badung.

Berdasarkan analisis yang telah disampaikan melalui penelitian ini terkait upaya penanggulangan konversi lahan pertanian di lingkungan Subak Saih Kecamatan Kuta Utara dapat dilakukan melalui beberapa penanganan sebagai berikut.

1) Faktor pertumbuhan kota dengan signifikansi hasil analisis sebesar 0,822 menunjukkan hubungan signifikan terhadap terjadinya konversi lahan pertanian di Subak Saih. Hal ini dipicu oleh beberapa indikator yaitu usaha pemenuhan kebutuhan fisiologis, laju investasi dengan mengkonversi lahan pertanian, pola prilaku masyarakat melalui gaya hidup dan kepadatan penduduk di wilayah Subak Saih Kecamatan Kuta Utara. Fenomena ini harus dikelola dengan baik untuk mengatahu laju konversi di wilayah tersebut.

2) Faktor ekonomi dengan signifikansi hasil analisis sebesar 0,929 menunjukkan hubungan signifikan terhadap terjadinya konversi lahan pertanian di Subak Saih. Secara teoretis konversi lahan yang dilatar belakangi oleh faktor ekonomi dipicu oleh pendapatan diperoleh petani melalui hasil produksi, kondisi serapan pasar terhadap hasil panen, implikasi terhadap ekspektasi penghasilan usaha, dan pengaruh lingkungan.

3) Faktor sosial dengan signifikansi hasil analisis sebesar 0,690 menunjukkan hubungan signifikan terhadap terjadinya konversi lahan pertanian di Subak Saih. Terjadinya konversi lahan berdasarkan faktor sosial secara teoritis disebabkan oleh perkembangan kebutuhan hidup petani, penurunan minat masyarakat untuk bertani khususnya pada generasi muda, hubungan petani dengan kepemilikan lahan dan hubungan sosial pemilik lahan dan penggarap lahan.
4) Faktor teknologi dengan signifikansi hasil analisis sebesar 0,791 menunjukkan hubungan signifikan terhadap terjadinya konversi lahan pertanian di Subak Saih. Secara teoretis masalah ini dipandang bersumber dari beberapa indikator yaitu pemanfaatan teknologi dalam pertanian, intensifikasi pertanian dan idiologi berpikir petani. Perlu adanya efektifitas terhadap pemanfaatan teknologi pertanian yang saat ini masih belum mampu diberdayaakan oleh petani secara umum.

5) Faktor aksesibilitas dengan signifikansi hasil analisis sebesar 0,979 menunjukkan hubungan signifikan terhadap terjadinya konversi lahan pertanian di Subak Saih. Berdasarkan signifikansi teoritis masalah ini dipicu oleh beberapa indikator yaitu: akses menuju lahan pertanian, jarak antar lahan pertanian, dan kemudahan biaya operasional menjadi salah satu masalah substansial pada petani Subak Saih.

6) Faktor risiko dan ketidak pastian dengan signifikansi hasil analisis sebesar 0,723 menunjukkan hubungan signifikan terhadap terjadinya konversi lahan pertanian di Subak Saih. Fenomena ini disebabkan oleh beberapa indikator seperti : proteksi ekonomi, penanggulangan terhadap kegagalan panen dan penanggulangan ketidakpastian faktor alam hendaknya menjadi perhatian penting bagi petani. Proteksi ekonomi seperti kepemilikan asuransi pertanian, perencanaan yang baik tentang sistem pertanian perlu mendapat perhatian signifikan.

7) Faktor lahan sebagai asset dengan signifikansi hasil analisis sebesar 0,888 menunjukkan hubungan signifikan terhadap terjadinya konversi lahan pertanian di Subak Saih. Kondisi ini disebabkan oleh beberapa faktor seperti: perawatan lahan pertanian, pengelolaan sistem pertanian, pemahaman ekologis dan ketahanan dan proteksi lahan dapat digunakan sebagai landasan dalam membangun dan mempertahankan lahan pertanian.

\section{Hubungan faktor-faktor konversi lahan pertanian dengan kesejahteraan petani}

Hubungan faktor-faktor konversi lahan pertanian dengan kesejahteraan petani dapat diamati melalui hasil analisis sebagai berikut.

1) Hubungan aksesibilitas lahan terhadap kesejahteraan petani

Aksesibilitas dengan sumbangan pengaruh koefisien indikator paling besar dalam membentuk konversi lahan pertanian Subak Saih sebesar 0,979 berhubungan signifikan dengan kesejahteraan petani. Berkurangnya aksesibilitas salah satunya pada lahan akibat terjadinya konversi ternyata melemahkan kepercayaan diri petani dalam 
mempertahankan lahan garapannya sehingga kemudian ikut mengkonversi lahan.

2) Hubungan faktor ekonomi terhadap kesejahteraan petani

Faktor ekonomi dengan sumbangan pengaruh koefisien sebesar 0,929 berhubungan dengan kesejahteraan petani. Peningkatan kebutuhan masyarakat yang mengarah pada masyarakat konsumtif sangat mempengaruhi tatanan ekonomi petani di Subak Saih, Kecamatan Kuta Utara. Motif ekonomi sebagai implikasi dari kesejahteraan membuat petani menggunakan konversi sebagai langkah alternatif dalam memenuhi kebutuhan ekonominya.

3) Hubungan faktor lahan sebagai asset dengan kesejahteraan petani

Lahan sebagai asset dengan sumbangan pengaruh koefisien indikator sebesar 0,888. Mengingat bahwasannya kebutuhan lahan hunian yang semakin meningkat berhubungan secara horisontal terhadap semakin banyaknya pengembang properti yang mendesak lahan pertanian masyarakat menjadi lahan komoditas atau lahan hunian. Lahan sebagai asset sebagai salah satu penyebab konversi berhubungan signifikan dengan kesejahteraan petani.

4) Hubungan faktor pertumbuhan kota dengan kesejahteraan petani

Faktor Pertumbuhan Kota dipandang berhubungan signifikan dengan kesejahteraan petani dengan sumbangan pengaruh koefisien indikator sebesar 0,833. berhubungan dengan kesejahteraan petani. Semakin berkembangnya sebuah perkotaan yang berbatasan langsung dengan lahan pertanian secara tidak langsung mempengaruhi sirkulasi dan mekanisme pertanian yang ada.

5) Hubungan faktor teknologi pertanian dengan kesejahteraan petani

Hubungan selanjutnya adalah faktor teknologi dengan sumbangan pengaruh koefisien indikator sebesar 0,791. Hasil penelitian ini menandakan bahwa pemanfaatan teknologi pertanian yang kurang efisien menjadi salah satu penyebab terjadinya konversi lahan di lingkungan Subak Saih. Pemanfaatan teknologi pertanian dan manajemen agribisnis apabila dilakukan dengan baik mampu memberikan peningkatan kesejahteraan petani.

6) Hubungan faktor risiko dan ketidak pastian dengan kesejahteraan petani

Hubungan selanjutnya melalui risiko dan ketidak pastian dengan sumbangan pengaruh koefisien indikator sebesar 0,722. Dengan hasil penelitian tersebut maka dapat disimpulkan bahwa risiko dan ketidakpastian sebagai salah satu faktor peyebab konversi memiliki hubungan dengan kesejahteraan petani.
Perbaikan pada pengelolaan lahan dan perhitungan klimatologis seperti cuaca, suhu dan iklim menjadi penting untuk dipahami petani dalam memanajemen model penanaman.

7) Hubungan faktor sosial dengan kesejahteraan petani

Hubungan terahir adalah faktor sosial dengan sumbangan pengaruh koefisien indikator sebesar 0,690. Hasil analisis ini menunjukkan bahwa faktor sosial sebagai penyebab konversi memiliki peranan yang cukup signifikan sdengan kesejahteraan petani di Subak Saih Kecamatan Kuta Utara Kabupaten Badung. Sehubungan dengan deskripsi data tersebut di atas, faktor konversi lahan pertanian di Subak Saih berhubungan dengan kesejahteraan petani.

\section{SIMPULAN DAN SARAN}

\section{Simpulan}

Berdasarkan hasil dan pembahasan yang telah dilakukan dalam penelitian ini, dapat disimpulkan sebagai berikut:

1) Faktor-faktor yang mempengaruhi konversi lahan di Subak Saih, Kecamatan Kuta Utara terdiri atas: faktor pertumbuhan, ekonomi, sosial, teknologi, aksesibilitas, risiko dan ketidak pastian dan lahan sebagai asset.

2) Hubungan konversi lahan pertanian dengan kesejahteraan petani menunjukkan bahwa : faktor aksesibilitas, ekonomi, lahan sebagai asset, pertumbuhan kota, teknologi, risiko dan ketidak pastian, dan sosial berhubungan dengan kesejahteraan petani.

\section{Saran}

Saran yang dapat diajukan dari hasil penelitian ini adalah sebagai berikut.

1) Seluruh pihak terkait baik pemerintah maupun prajuru subak harus mampu untuk mengontrol laju konversi lahan dengan mempertegas sangsisangsi bagi anggota subak yang melakukan alih fungsi lahan, mempertegas peraturan-peraturan pemerintah, memperbaiki manajemen pertanian dan memberikan komvensasi berupa insentif, asuransi, bebas pajak dan memberikan beasiswa bagi anak petani.

2) Petani harus ditekankan bahwa konversi lahan bukan jalan terbaik bahkan dapat merugikan petani itu sendiri dan secara luas seperti ketahanan pangan serta lingkungan. Penelitian terkait faktor-faktor konversi lahan serta hubungannya terhadap kesejahteraan petani perlu dikaji lebih lanjut guna mengendalikan tingkat konversi lahan pertanian.

\section{UCAPAN TERIMAKASIH}

Dwi Andika, et.al., Faktor-faktor...|11 
Melalui e-jurnal ini penulis mengucapkan terimakasih dengan tulus kepada segenap anggota dan pengurus organisasi Subak Saih atas komitmen yang telah diberikan guna terselesaikannya penelitian ini.

\section{DAFTAR PUSTAKA}

Arikunto, Suharsimi. 2013. Prosedur Penelitian Suatu Pendekatan Praktik. Rineka Cipta, Jakarta

Irawan, B. 2004. Solusi Konversi Lahan Melalui Pendekatan Sosial Ekonomi. Bogor: Pusat Penelitian dan Pengembangan Sosial Ekonomi Pertanian.

Notohadikusumo, T. 2005. "Implikasi Etika Dalam Kebijakan Pembangunan Kawasan" (Dalam Majalah "Forum Perencanaan Pembangunan - Edisi Khusus, Januari 2005").

Maharani, T. 2006. Analisis Pendapatan dan Tingkat Kesejahteraan Transmigrasi di Unit Pemukiman Transmigrasi Propinsi Lampung. Skripsi. Bogor: Program Studi Ekonomi Pertanian dan Sumberdaya Fakultas Pertanian Institut Pertanian Bogor.

Penyusun. 2013. Sensus Pertanian 2013: Badan Pusat Statistik :Jakarta

Sudibyo, Bambang. 2012. Faktor-faktor yang Mempengaruhi Konversi Lahan Pertanian terhadap Pemenuhan Kebutuhan Rumah Tangga Di Desa Candimulyo (Tesis). Wonosobo : Universitas Diponegoro.

Santosa. 2008. Faktor-faktor yang Mempengaruhi Keputusan Petani Mengkonversi Lahan Pertanian Menjadi Lahan Non Pertanian Di Desa Kopeng (Tesis). Semarang : Universitas Diponegoro.

Utomo, M., Eddy Rifai dan Abdulmutalib Thahir. 1992. Pembangunan dan Alih Fungsi Lahan. Lampung: Universitas Lampung.

Winarno, Budi. 2002. Teori dan Proses Kebijakan Publik. Yogyakarta: Media.

Windia, Wayan. 2006. "Transformasi Sistem Irigasi Subak yang Berlandaskan Tri Hita. Karana" (disertasi). Yogyakarta: PPS-UGM. 